\title{
Characterization of Antifungal Metabolites from Antagonistic Fluorescent Pseudomonads
}

\author{
Fathalla Alaa M. ${ }^{1}$; Samy A. M. Abd El-Azeem ${ }^{2}$; Metwaly A. Baraka ${ }^{1}$ and Elshahat M. $\operatorname{Ramadan}^{3}$ \\ ${ }^{1}$ Department of Agricultural Botany, Faculty of Agriculture, Suez Canal University, Ismailia, Egypt \\ ${ }^{2}$ Department of Soil and Water, Faculty of Agriculture, Suez Canal University, Ismailia, Egypt \\ ${ }^{3}$ Department of Agricultural Microbiology, Faculty of Agriculture, Ain-Shams University, Cairo, Egypt
}

Received: $1 / 9 / 2015$

\begin{abstract}
Many Pseudomonas species produce antimicrobial metabolites for pathogen suppression and stimulate the plant growth. So twenty fluorescent pseudomonas strains showed highest antagonism efficiency to soilborne phytopathogens which used throughout the present investigation. These bacteria included five strains $P$. putida, $3 / P$. plecoglossicida, 3/ P. palleroniana, 2/ P. corrugate, 2/ P. entomophila and one from each of $P$. moraviensis, $P$. parafulva, $P$. mosselii, $P$. anguilliseptica, $P$. argentinensis. Detection of the genes that encode for the production of antibiotics by these strains such as phenazine-1-carboxylic acid (PCA), phenazine-1-carboxamide (PCN), pyrrolnitrin (PRN), and pyoluteorin (PLT) was done by polymerase chain reaction (PCR) using gene-specific primers. Results clearly showed that eight Pseudomonas strains produced (PCA), twelve strains produced (PCN), nine strains produced (PLT) and two strains produced (PRN). Polymerase chain reaction (PCR) confirmed the obtained result by using TLC. P. putida (SAW19) gave the highest antagonistic potential against tested phytopathogenic fungi and formulated using different carriers to test for its viability on different carriers. The populations of $P$. putida were markedly higher in vermiculite compared with the carriers under six months incubation period.
\end{abstract}

Keywords: fluorescent pseudomonas-PCA-PLT-PRN-PCN-TLC

\section{INTRODUCTION}

A huge number of fungal diseases plague the crop plants throughout the year when a farmer fails to take proper preventative measures. Plant disease control has become heavily dependent on fungicides to combat the wide variety of fungal diseases. Beneficial bacteria have been intensively studied as biocontrol agents against soilborne diseases (Weller, 2007; Moeinzadeh et al., 2010; Saber et al., 2015). Good results have been obtained with Gram-negative bacteria Pseudomonas spp. in the control of several plant pathogens, including Gaeumannomyces graminis var. tritici, Fusarium spp., and Pythium spp. (Raaijmakers et al., 2006; Mavrodi et al., 2012). Among the great variety of beneficial bacteria and antibiotic metabolites already discovered, our attention has been focused on phenazines, pyrroltype antibiotics and pyo-compounds. Antibiotics and some strains, e.g. P. fluorescens strains $\mathrm{CHA} 0$ and $\mathrm{Pf}-5$, produce multiple antibiotics. In general, these antibiotics have broad-spectrum toxic activity against fungi, bacteria, protozoa, nematodes, and sometimes also against plants or even viruses (Raaijmakers et al., 2006).

Various types of material can be used as carrier for seed or soil inoculation. A suitable biofertilizer carrier should meet the following criteria: (1) it should be available in powder or granule forms; (2) it should be able to support microorganism growth and survival, and easily release functional microorganisms into the soil; (3) it should have a strong moisture absorption capability, good aeration characteristics, and excellent $\mathrm{pH}$ buffering capacity; (4) it should be non-toxic and environmentally friendly; (5) it should be easily sterilized, manufactured, and handled in the field, and have good storage qualities; and (6) it should be cheap (Stephens and Rask, 2000; Rebah et al., 2002; RiveraCruz et al., 2008). Several alternative solid materials have been evaluated as inoculant carriers, such as: soil, vermiculite, perlite, ground rock phosphate, polyacrylamide gel, alginate, decomposed sawdust, coal, compost made from bagasse, sawdust, plant residues compost, farmyard manure and volcanic pumice (Strijdom and Deschodt, 1976; Einnarsson et al., 1993; Brockwell and Bottomley, 1995; Stephens and Rask, 2000; Hungria et al., 2005). Vermiculite and perlite are cheap and readily available components, both are light weight and pH-neutral (Goh and Haynes, 1977; Atiyeh et al., 2000). Perlite was a good carrier material because of its light weight, its porosity, and its environmental-friendliness (Khavazi et al., 2007).

\section{MATERIALS AND METHODS}

\section{Source of fluorescent pseudomonads}

In the present investigation, twenty fluorescent pseudomonads strains were obtained from Botany Department, Fac. Agric., Suez Canal Univ. These strains which showed the highest efficiency to antagonize soilborne phytopathogens were isolated and identified (using gene sequencing) by Fthalla (Alaa) et al. (2015). The strains are Pseudomonas entomophila SAW7, Pseudomonas plecoglossicida SAB1, Pseudomonas mosselii SAW1, Pseudomonas corrugata SAC1, Pseudomonas moraviensis SAw15, Pseudomonas palleroniana SAB17, Pseudomonas palleroniana SAB15, Pseudomonas parafulva SAB14, Pseudomonas putida SAB12, Pseudomonas plecoglossicida SAB8, Pseudomonas putida SAB10, Pseudomonas putida SAW3, Pseudomonas corrugata SAW23, Pseudomonas anguilliseptica SAW24, Pseudomonas palleroniana SAW21, Pseudomonas putida SAW22, Pseudomonas putida SAW19, Pseudomonas plecoglossicida SAW10, Pseudomonas argentinensis SAW9 and Pseudomonas entomophila SAW5. 


\section{Detection of Pseudomonas strains antimetabolites 1-Phenazine production}

Phenazine compounds were extracted from KB plates with fully grown selected bacteria. The plates were washed twice with sterile water to remove bacterial colonies. Agar was excised in small pieces and pooled in Erlenmeyer flasks. Twelve milliliters of chloroform was added and the suspension was shaken at $37^{\circ} \mathrm{C}$ for $2 \mathrm{hr}$. The chloroform was air-dried and the extract was dissolved in $60 \mu \mathrm{l}$ methanol. The $30 \mu \mathrm{l}$ of methanol extracts was spotted on silica gel plates (Kieselgel 60 F254; Merck, VWR, Leuven, Belgium). The plates were developed in a solvent mixture of toluene/acetone $(3: 1 \mathrm{v} / \mathrm{v})$ and visualized under UV light. Pseudomonas fluorescens CMR12a was included as positive control (Perneel et al., 2007).

\section{2- Detection and Extraction Pyrrolnitrin and Pyoluteorin}

Detection of Pyoluteorin (PLT) was made by thinlayer chromatography (TLC), bacterial strains were grown in $25 \mathrm{ml}$ of $\mathrm{KB}$ broth in $50-\mathrm{ml}$ screw cap vials for 14 days without shaking at $25{ }^{\circ} \mathrm{C}$. Bacterial strains were grown in $25 \mathrm{ml}$ of a minimal medium as described by De Souza and Raaijmakers (2003). Bacterial isolates were shaken at $180 \mathrm{rpm}$ for $24 \mathrm{~h}$ at $25{ }^{\circ} \mathrm{C}$ and subsequently incubated at $25{ }^{\circ} \mathrm{C}$ in the dark for 4 additional days without shaking. Extraction of pyrrolnitrin and pyoluteorin from bacterial cultures was carried out as described by De Souza and Raaijmakers, (2003). To detect PRN by TLC, $15 \mathrm{ml}$ of bacterial culture was centrifuged for $15 \mathrm{~min}$ at $8700 \times \mathrm{x}$, supernatant was discarded and the cells were extracted twice with $5 \mathrm{ml}$ of ethylacetate by sonicating the mixture for $3 \mathrm{~min}$. For PLT, $15 \mathrm{ml}$ of bacterial culture broth was extracted twice with $5 \mathrm{ml}$ of ethylacetate. The organic phase was evaporated to dryness and the residue was resuspended in $150 \mu$ l ethylacetate. A volume of 50 $\mu \mathrm{l}$ was spotted on $0.25 \mathrm{~mm}$ silica gel plate $(20 \times 20 \mathrm{~cm}$, aluminum oxide 60 F254). Separation was performed with chloroform: acetone $(9: 1 \mathrm{v} / \mathrm{v})$ as the solvent system. The corresponding PRN spots were detected by spraying with $2 \%$-dimethyl amino benzaldehyde (Ehrlich's reagent, Sigma Aldrich Chemie B. V., Bornem, Belgium). Pyoluteorin spots were detected by spraying with an aqueous $0.5 \%$ fast blue RR salt solution (Sigma Aldrich Chemie B. V., Bornem, Belgium). The retardation factor (Rf) values were 0.80 for PRN and 0.26 for PLT, as determined by migration of pure PRN, and confirmed by identical color) crimson spot) and $\mathrm{Rf}$ values reported for PLT.

\section{Screening of antimetabolites by polymerase chain reaction}

Detection of the genes that encode for the production of antibiotics such as phenazine-1-carboxylic acid (PCA), phenazine-1-carboxamide (PCN), pyrrolnitrin (PRN), and pyoluteorin (PLT) was done by PCR using gene-specific primers. The primer sets and the amplification conditions for the screening of gene encoding antibiotics are listed in Table (1). The PCR reaction mixture consisted of $1 \mu \mathrm{l}$ template DNA, 0.25 $\mu 1$ Taq DNA polymerase, $10 \mu \mathrm{l} 5 \mathrm{x}$ reaction buffer, $2.5 \mu \mathrm{l}$ of each primer, $1 \mu \mathrm{dNTPs}$ and add distilled water to a final volume of $50 \mu 1$.

Table (1): Primer and amplification conditions for the different PCR based screenings of genes that encode for antibiotics

\begin{tabular}{|c|c|c|c|}
\hline Primers & Primer sequence & Reference & Amplification conditions \\
\hline $\begin{array}{l}\text { PCA } \\
\text { PCA2a } \\
\text { PCA3b }\end{array}$ & $\begin{array}{l}\text { 5'-TTGCCAAGCCTCGCTCCAAC 3'; } \\
\text { 5'-CCGCGTTGTTCCTCGTTCAT 3' }\end{array}$ & $\begin{array}{r}\text { (Raaijmakers } \\
\text { et al.,1997) }\end{array}$ & $\begin{array}{l}\text { Initial denaturation at } 94^{\circ} \mathrm{C} \\
\text { for } 3 \mathrm{~min} ; 30 \text { cycles of } 94^{\circ} \mathrm{C} \\
\text { for } 60 \mathrm{~s}, 58^{\circ} \mathrm{C} \text { for } 45 \mathrm{~s} \text {, and } \\
72^{\circ} \mathrm{C} \text { for } 60 \mathrm{~s} \text {; final extension } \\
\text { at } 72^{\circ} \mathrm{C} \text { for } 10 \mathrm{~min} \text {. }\end{array}$ \\
\hline $\begin{array}{l}\text { PCN } \\
\text { PhzH-up } \\
\text { PhzH-low }\end{array}$ & $\begin{array}{c}\text { 5'-CGCACGGATCCTTTCAGAATGTTC-3' } \\
\text { 5'-GCCACGCCAAGCTTCACGCTCA-3' }\end{array}$ & $\begin{array}{l}\text { (Mavrodi } \\
\text { et al., 2001) }\end{array}$ & $\begin{array}{l}\text { Initial denaturation at } 94^{\circ} \mathrm{C} \\
\text { for } 3 \mathrm{~min} ; 30 \text { cycles of } 94^{\circ} \mathrm{C} \\
\text { for } 60 \mathrm{~s}, 67.2^{\circ} \mathrm{C} \text { for } 45 \mathrm{~s} \text {, and } \\
72^{\circ} \mathrm{C} \text { for } 60 \mathrm{~s} \text {; final extension } \\
\text { at } 72^{\circ} \mathrm{C} \text { for } 10 \mathrm{~min} .\end{array}$ \\
\hline $\begin{array}{l}\text { PRN } \\
\text { Prncf } \\
\text { Prncr }\end{array}$ & $\begin{array}{c}\text { 5'-CCACAAGCCCGGCCAGGAGC-3' } \\
\text { 5'-GAGAAGAGCGGGTCGATGAAGCC-3' }\end{array}$ & $\begin{array}{c}\text { (Mavrodi } \\
\text { et al., 2001) }\end{array}$ & $\begin{array}{l}\text { Initial denaturation at } 94^{\circ} \mathrm{C} \\
\text { for } 2 \mathrm{~min} ; 30 \text { cycles of } 94^{\circ} \mathrm{C} \\
\text { for } 1 \mathrm{~min}, 58^{\circ} \mathrm{C} \text { for } 45 \mathrm{~s} \text {, and } \\
72^{\circ} \mathrm{C} \text { for } 1 \mathrm{~min} \text {; final } \\
\text { extension at } 72^{\circ} \mathrm{C} \text { for } 10 \mathrm{~min}\end{array}$ \\
\hline $\begin{array}{c}\text { PLT } \\
\text { PLTC1 } \\
\text { PLTC2 }\end{array}$ & $\begin{array}{l}\text { 5'-AACAGATCGCCCCGGTACAGAACG-3' } \\
\text { 5'-AGGCCCGGACACTCAAGAAAACTCG-3' }\end{array}$ & $\begin{array}{l}\text { (De Souza et } \\
\text { al., 2003) }\end{array}$ & $\begin{array}{l}\text { Initial denaturation at } 95^{\circ} \mathrm{C} \\
\text { for } 2 \mathrm{~min} ; 30 \text { cycles of } 95^{\circ} \mathrm{C} \\
\text { for } 2 \mathrm{~min}, 67^{\circ} \mathrm{C} \text { for } 1 \mathrm{~min} \text {, and } \\
72^{\circ} \mathrm{C} \text { for } 1 \mathrm{~min} \text {; final } \\
\text { extension at } 72^{\circ} \mathrm{C} \text { for } 10 \mathrm{~min}\end{array}$ \\
\hline
\end{tabular}


A comparative study of different carriers on fluorescent pseudomonads

The objective of this experiment was selecting the suitable carrier for the $P$. putida (SAW19) that gave the highest results for antagonistic activity against phytopathogenic fungi.

The experiment consisted of six materials as carrier including rock phosphate, perlite, bentonite, rock phosphate + perlite + bentonite, vermuclite and vermuclite + rock phosphate + perlite + bentonite .

Fifty grams of tested carriers were dried at $70^{\circ} \mathrm{C}$ for $3 \mathrm{~h}$ to material dryness and the carriers were sterilized in an autoclave at $121^{\circ} \mathrm{C}$ for one hour (Pesenti et al., 1991). Then, they were placed in oven at $70^{\circ} \mathrm{C}$ for $3 \mathrm{~h}$ to dry out the material. The $\mathrm{pH}$ of all of the materials was adjusted to 7.0 thoroughly mixing by $\mathrm{CaCO}_{3}$ powder. Different combinations of these materials were prepared as described in Table (2) and packed in polyethylene bags.

Table (2): Different formulations of carrier materials and their field capacity

\begin{tabular}{|c|c|c|}
\hline No. & $\begin{array}{l}\text { Carrier } \\
\text { type }\end{array}$ & \begin{tabular}{llr}
$\begin{array}{l}\text { Added } \\
\text { suspension }\end{array}$ & \multicolumn{2}{c}{ Bacteria } \\
(ml) as \\
water & holding \\
capacity to $50 \mathrm{~g}$ & garrier material \\
calla
\end{tabular} \\
\hline 1 & Perlite & 77 \\
\hline 2 & Bentonite & 35 \\
\hline 3 & Rock phosphate & 9 \\
\hline 4 & Vermiculite & 62 \\
\hline 5 & $\begin{array}{l}\text { Rock phosphate }+ \\
\text { Perlite }+ \text { Bentonite }\end{array}$ & 33 \\
\hline 6 & $\begin{array}{l}\text { Vermiculite }+ \text { Rock } \\
\text { phosphate }+ \text { Perlite } \\
+ \text { Bentonite }\end{array}$ & 34 \\
\hline
\end{tabular}

Inoculant preparation and incubation

Fluorescent pseudomonads suspension was prepared in $1 \mathrm{~L}$ nutrient broth culture. For this purpose, proliferation was performed using a rotary shaker incubated at $28^{\circ} \mathrm{C}$ at $100 \mathrm{rpm}$. Then, suspension

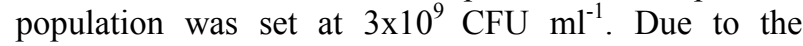
limited water holding capacity of applied carrier materials, new suspension cultures of bacteria according to the FC moisture content of carrier materials (Table 3) were added to each package and they were heat-sealed. Then, for uniform distribution of bacteria on each carrier, any package containing materials was well mixed and depending on the carrier material was kept for bacterial growth in the incubator at $28^{\circ} \mathrm{C}$ to the end of the 180 days (Shariati et al., 2013).

\section{Bacterial population in the carriers treatments}

Bacterial populations were counted at $0,15,30$, 60, 90, 120, 150 and 180 days, with three replicates. For this purpose, $1 \mathrm{~g}$ of carriers was removed in sterile conditions; 10-fold serial dilution (reached to $10^{-10}$ ) was prepared. After that resulting suspensions were cultured on $\mathrm{KB}$ agar medium. After one day incubation at $28^{\circ} \mathrm{C}$, plates containing 3-300 positive control plates (Pure culture fluorescent pseudomonads).

Table (3): Antagonistic metabolite production among the antagonistic Pseudomonas strains

\begin{tabular}{|c|c|c|c|c|}
\hline Pseudomonas strains & $\begin{array}{c}\mathbf{P C} \\
\mathbf{A}\end{array}$ & $\begin{array}{c}\mathbf{P C} \\
\mathbf{N}\end{array}$ & $\begin{array}{c}\mathbf{P L} \\
\mathbf{T}\end{array}$ & $\begin{array}{c}\text { PR } \\
\mathbf{N}\end{array}$ \\
\hline P. putida SAB12 & - & - & + & - \\
\hline P. putida SAB10 & - & + & - & - \\
\hline P. putida SAW3 & + & + & - & - \\
\hline P. putida SAW22 & - & - & + & - \\
\hline P. putida SAW19 & + & + & - & - \\
\hline P. plecoglossicida SAB1 & - & - & + & - \\
\hline P. plecoglossicida SAB8 & + & - & - & - \\
\hline P. plecoglossicida SAW10 & + & + & + & - \\
\hline P. palleroniana SAB15 & - & + & - & - \\
\hline P.palleroniana SAB17 & - & - & + & - \\
\hline P. palleroniana SAW21 & - & + & + & - \\
\hline P. corrugata SAC1 & - & - & - & - \\
\hline P. corrugata SAW23 & - & - & + & - \\
\hline P. entomophila SAW7 & - & + & + & - \\
\hline P. entomophila SAW5 & - & + & - & - \\
\hline P. moraviensis SAw15 & + & + & - & - \\
\hline P. parafulva SAB14 & + & + & - & - \\
\hline P. mosselii SAW1 & + & + & - & - \\
\hline P. anguilliseptica SAW24 & + & - & - & + \\
\hline P.rgentinensis SAW9 & - & + & + & - \\
\hline
\end{tabular}

+ present - absent

phenazine-1-carboxylic acid (PCA), pyrrolnitrin (PRN), phenazine-1-carboxamide (PCN) and pyoluteorin (PLT)

\section{RESULTS AND DISCUSSION}

Production of antifungal metabolites

Antifungal metabolites, phenazine-1-carboxylic acid (PCA), pyrrolnitrin (PRN), phenazine-1carboxamide (PCN) and pyoluteorin (PLT), were extracted from the fermentation cultures of all tested strains. Thin layer chromatography (TLC) confirmed the production of PCA by the eight pseudomonas strains (Pseudomonas mosselii SAW1, Pseudomonas moraviensis SAW15, Pseudomonas parafulva SAB14, Pseudomonas plecoglossicida SAB8, Pseudomonas putida SAW3, Pseudomonas anguilliseptica SAW24, Pseudomonas putida SAW19 and Pseudomonas plecoglossicida SAW10), PCN was confirmed by twelve strains (Pseudomonas entomophila SAW7, Pseudomonas mosselii SAW1, Pseudomonas moraviensis SAW15, Pseudomonas palleroniana SAB15, Pseudomonas parafulva SAB14, Pseudomonas putida SAB10, Pseudomonas putida SAW3, Pseudomonas palleroniana SAW21, Pseudomonas 
putida SAW19, Pseudomonas plecoglossicida SAW10, Pseudomonas argentinensis SAW9 and Pseudomonas entomophila SAW5), PLT was confirmed by nine strains (Pseudomonas entomophila SAW7, Pseudomonas plecoglossicida SAB1, Pseudomonas palleroniana SAB17, Pseudomonas putida SAB12, Pseudomonas corrugata SAW23, Pseudomonas palleroniana SAW21, Pseudomonas putida SAW22,
Pseudomonas plecoglossicida SAW10 and Pseudomonas argentinensis SAW9), and PRN was confirmed by two strains (Pseudomonas palleroniana SAB15 and Pseudomonas anguilliseptica SAW24 ) as presented in Table (3). The retardation factor (Rf) values were $0.27,0.53,0.80$ and 0.26 for PCN, PCA, PRN and PLT, respectively, as determined by comigration with pure standards as shown in Fig. (1).
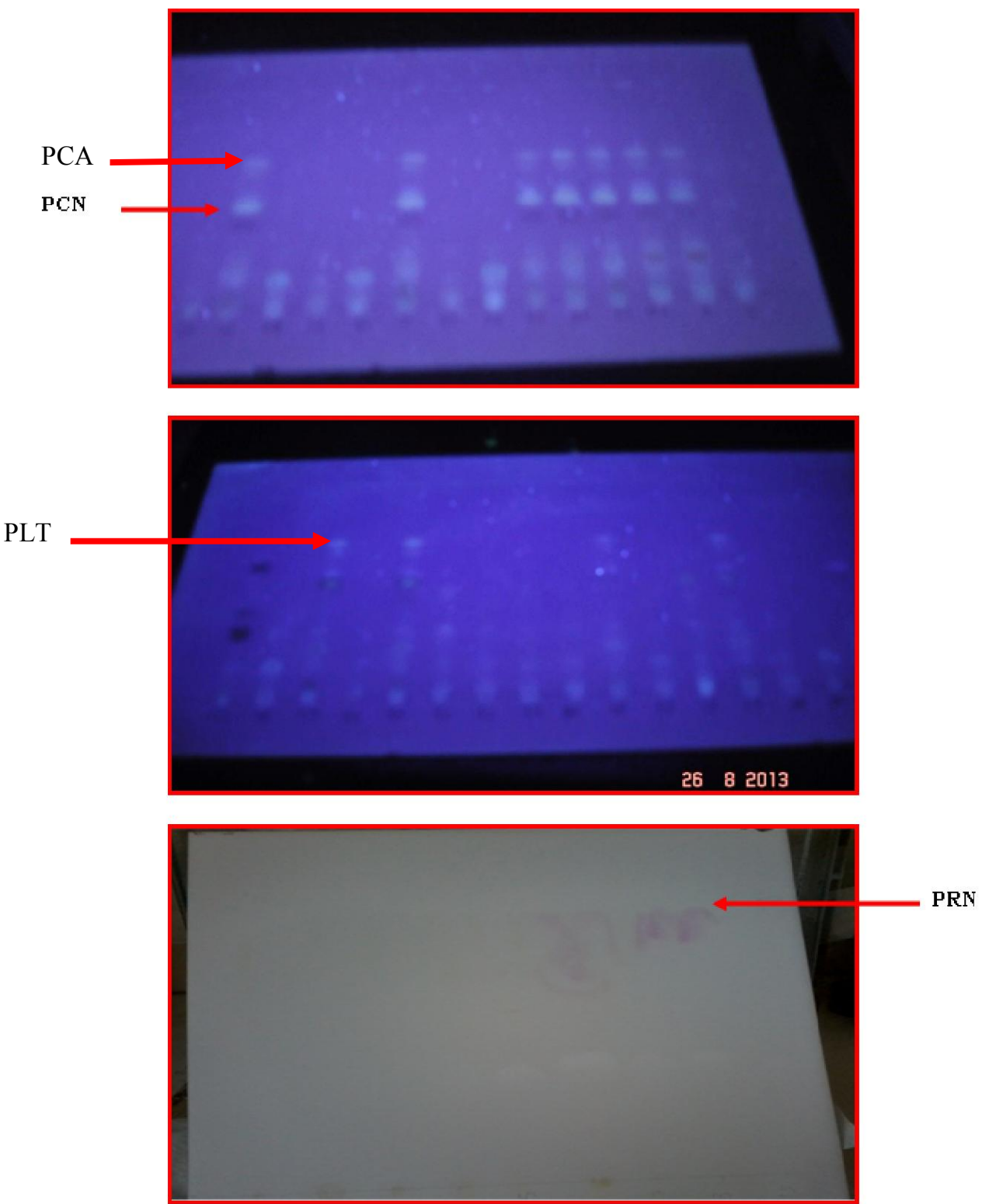

Fig. (1): Thin layer chromatography TLC analysis under ultra violet light of organic solvent extracts of King B agar cultures of Pseudomonas strains.

*phenazine-1-carboxylic acid (PCA), pyrrolnitrin (PRN), phenazine-1-carboxamide (PCN) and pyoluteorin (PLT)

Several strains of fluorescent pseudomonads such as $P$. fluorescence produce the broad-spectrum antibiotic of phenazine (Mark et al., 1995). Specifically, phenazine-1-carboxylic acid can be produced by fluorescent Pseudomonads such as $P$. fluorescens (Gurusiddaiah et al., 1986), P. chlororaphis (Pierson and Thomashow, 1992) and $P$. aeuroginossa (Anjaiah et al., 1998). Additionally, Production of phenazine-1carboxamide had been reported in fluorescent pseudomonads such as $P$. aeuroginossa and $P$. chlororaphis (Chin-A-Woeng et al., 1998; Mavrodi et al., 2001; kumar et al., 2005). Pyrrolnitrin can be produced by several strains of Pseudomonas and Burkholderia (Ligon et al., 2000). Pyoluteorin is produced by several pseudomonas sp., including strains that suppress plant diseases caused by phytopathogenic fungi (Bender et al., 1999). 


\section{Screening of antimetabolites by polymerase chain reaction (PCR)}

Total DNA of antagonistic fluorescent pseudomonad strains were tested in PCR using genespecific primers of PCA, PLT, PRN and PCN. PCA2a and PCA $3 b$ amplified the DNA fragment (1100-bp) corresponding to that of PCA which is a key gene in the biosynthesis of PCA in the tested strains and in the reference strain Pseudomonas CMR5c. PhzH-up and PhzH-low amplified the DNA fragment (2000-bp) corresponding to that of $\mathrm{PhzH}$, which is a key gene in the biosynthesis of PCN in the tested strains and in the reference strain Pseudomonas CMR12a. Prncf and Prncr amplified the DNA fragment (786-bp) corresponding to that of PRN which is a key gene in the biosynthesis of PRN in the tested strains and in the reference strain Pseudomonas CMR5c. PLTC1 and PLTC2 amplified the DNA fragment (779-bp) corresponding to that of PLT which is a key gene in the biosynthesis of PLT in the test strains and in the reference strain Pseudomonas CMR5c. The presence of different antimetabolites of teted antagonistic Pseudomonas strains were observed being eight Pseudomonas strains showed the presence of PCA genes (Fig. 2), twelve strains amplified PCN (Fig. 3), two strains amplified PRN (Fig. 4), nine strains amplified PLT (Fig. 5) and one antagonistic strain did not show any amplification of PCA, PLT, PRN and PCN. Detection of genes of specific functions in antagonistic fluorescent pseudomonads by polymerase chain reaction (PCR) confirmed the results obtained by thin layer chromatography (TLC) as shown in Table (3).

It means that the tested pseudomonas strains had the ability to produce different antifungal metabolites (PCA, PCN, PLT, and PRN). The ability of these organisms to produce these compounds highly varied from one strain to another. Pseudomonas plecoglossicida SAW10 showed high efficiency to produce three antimetabolites PCA, PCN and PLT as compared with other tested Pseudomonas strains. Consequantly, one tested strain did not show any activity to produce any of the observed antimetabolites (Pseudomonas corrugata SAC1). These results are in accordance with many investigators. Gurusiddaiah et al. (1986) stated that fluorescent pseudomonas as $P$. fluorescence had the ability to produce phenazine-1carboxylic acid (PCA). Pierson and Thomashow, (1992) and Anjaiah et al. (1998) confirmed that $P$. chlororaphis and $P$. aeurogenosa had the ability to produce PCA. Production of phenazine-1-carboxemide (PCN) had been reported in fluorescent pseudomonads such as $P$. aeurogenosa and P. chlororaphis (Chin-A-Woeng et al., 1998; Mavrodi et al., 2001 and Kumar et al., 2005). Pyoluteorin (PLT) and Pyrrolnitrin (PRN) are the broad spectrum antifungal metabolites produced by several pseudomonas species (Bender et al., 1999; Dwivedi and Johri, 2003).

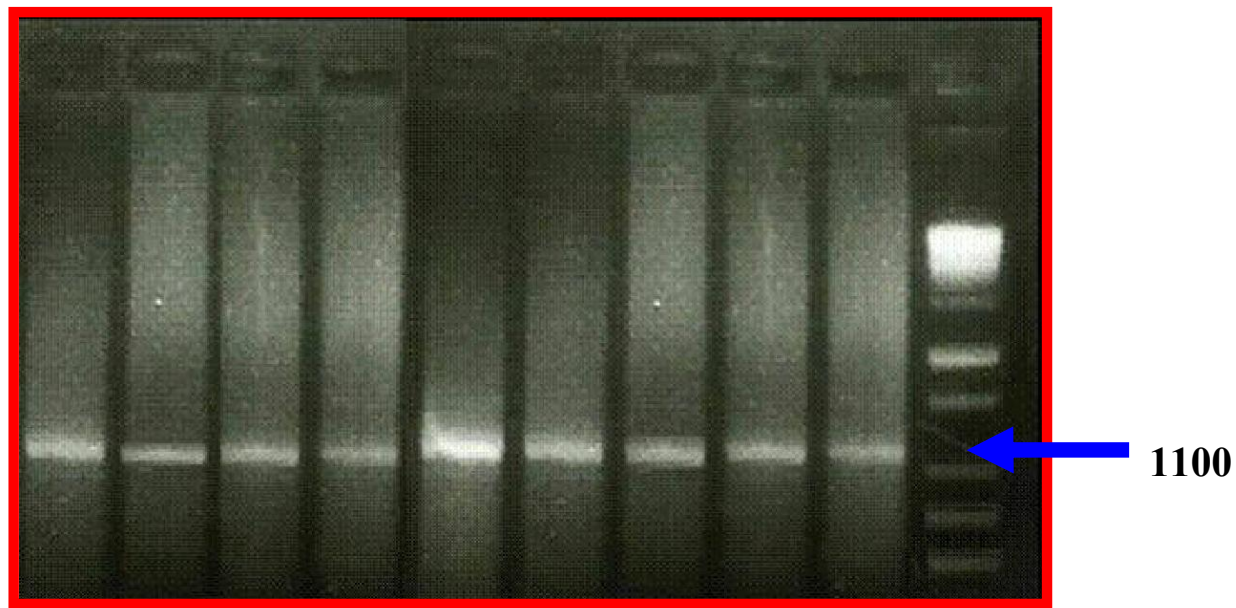

Fig. (2): Detection of phenazine-1-carboxylic acid (PCA) gene by PCR. Positive fluorescent pseudomonad strains showed the amplification of DNA fragment of PCA (1100 bp).

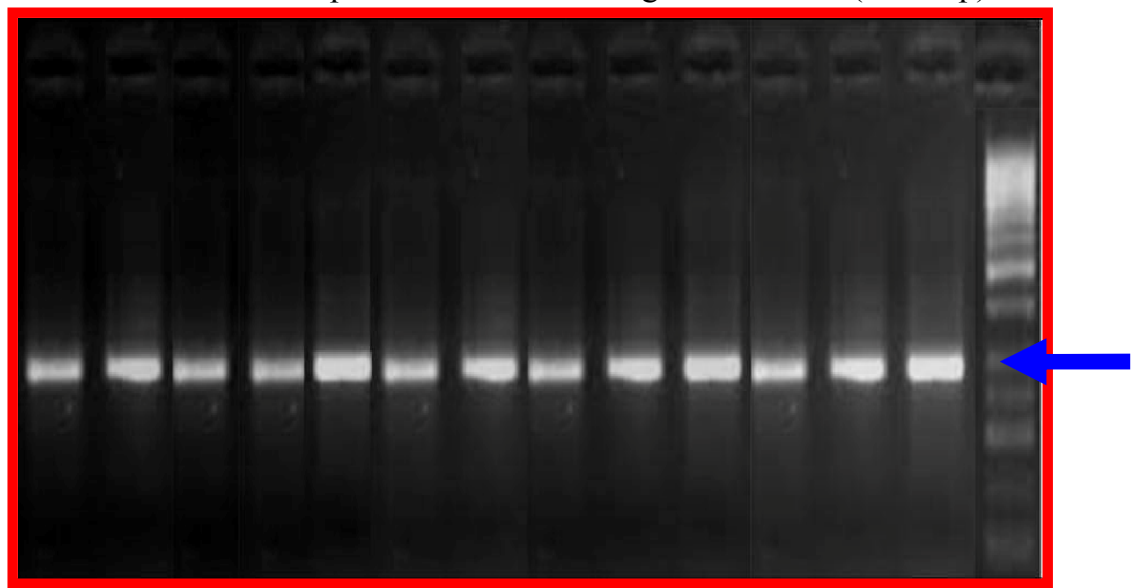

Fig. (3): Detection of phenazine-1-carboxamide (PCN) gene by PCR. Positive fluorescent pseudomonad strains showed the amplification of DNA fragment of PCN (2000 bp). 


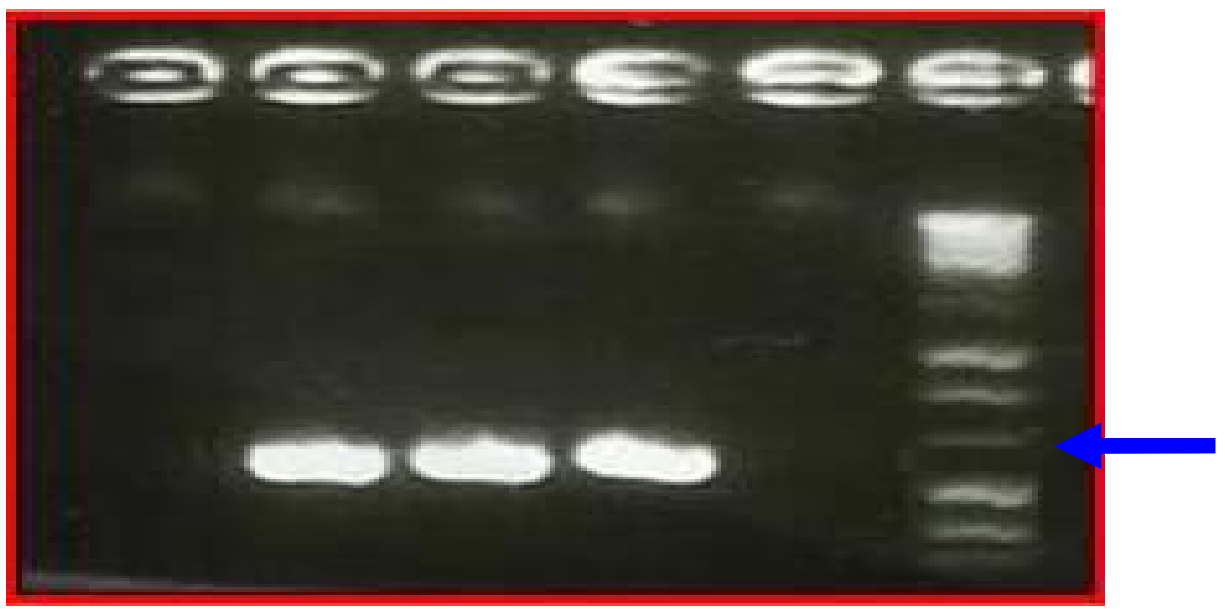

Fig. (4): Detection of pyrrolnitrin (PRN) gene by PCR. Positive fluorescent pseudomonad strains showed the amplification of DNA fragment of PRN (786 bp).

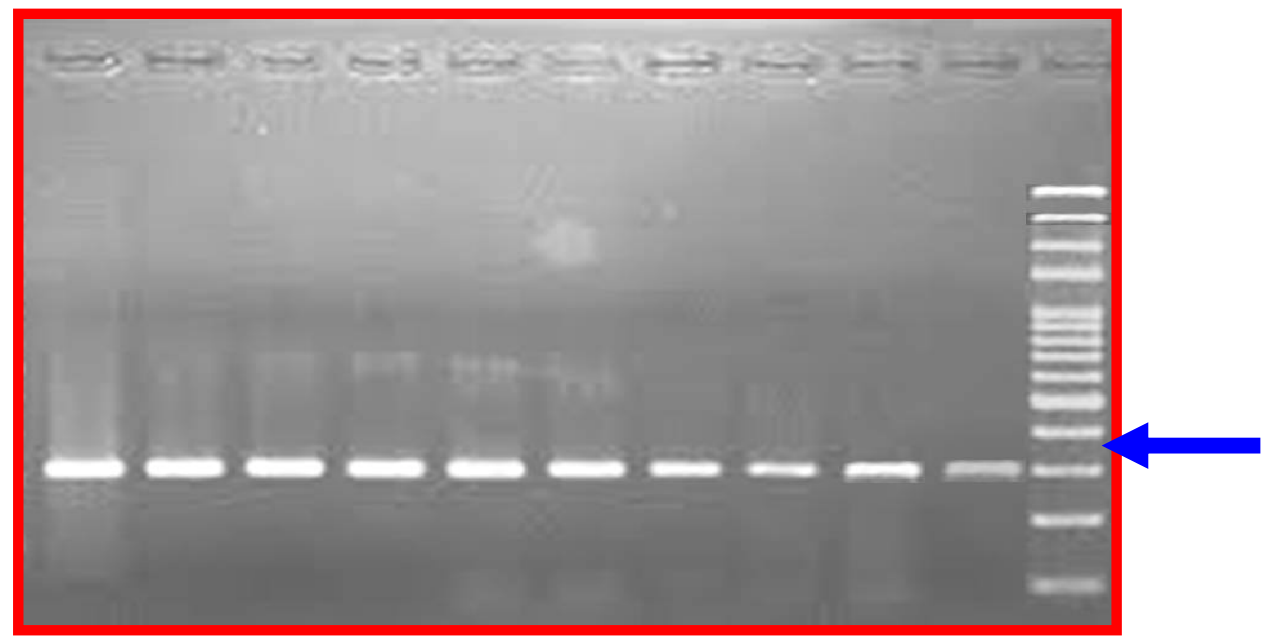

Fig. (5): Detection of pyoluteorin (PLT) gene by PCR. Positive fluorescent pseudomonad strains showed the amplification of DNA fragment of PLT (779 bp).

\section{Survival of $P$. putida on different carriers}

Psudomonas putida (SAW19) gave the highest antagonistic potential against tested phytopathogenic fungi by the same author (Mohamed et al., 2015). Therefore, the objective of this part was to evaluate the capacity and survival of $P$. putida strain for a long time on different carrier materials individually or mixtures during the incubation period (six months). Six different formulations were prepared using different carrier materials namely, rock phosphate $(\mathrm{R})$, perlite $(\mathrm{P})$, bentonite (B), mixture of $\mathrm{R}+\mathrm{P}+\mathrm{B} \quad(1: 1: 1 \quad w / w)$, vermiculite $(\mathrm{V})$ and mixture of $\mathrm{R}+\mathrm{P}+\mathrm{B}+\mathrm{V} \quad(1: 1: 1: 1$ $w / w)$. Survival of $P$. putida strain on different inoculant carriers in logarithmic scale of colony forming units (CFU) was shown in Fig. (6). The obtained results showed that the tested carriers have a different capacity to maintain an adequate survival of the $P$. putida strain. Also, results showed that the initial populations of $P$. putida in all tested carriers are greatly varied and the values ranged approximately from 7.2 to $9.0 \log _{10} \mathrm{CFU}$ $\mathrm{g}^{-1}$ and then gradually decreased over time. The count of viable $P$. putida cells after six months was conserved at the average of $5.3-8.0 \log _{10} \mathrm{CFU} \mathrm{g} \mathrm{g}^{-1}$ in all the tested carrier materials. Specifically, the populations of $P$. putida were sharply decreased in the inoculant carrier's rock phosphate, perlite and bentonite. However, numbers of $P$. putida slightly decline in the mixture of $\mathrm{R}+\mathrm{P}+\mathrm{B}$ carriers as compared to individually carriers (Fig. 6). The lack of organic matter in these materials leads to decline the populations, indicating that the limitation of nutrients and growth conditions for $P$. putida. Cigdem and Merih (2005) depicted that the drying process and production of toxins mainly deceased the bacterial population during incubation period. Based on the previous results, the current study concluded that perlite is not suitable substrate for survival $P$. putida. On the contrary, perlite is a suitable substrate for bacterial growth and was effective as peat in maintaining high populations of rhizobia and $B$. megaterium (Daza et al., 2000; Khavazi et al., 2007). Similarly, previous study has also shown that perlite was superior for maintaining survival of several rhizobia and plant growth promoting bacteria (Albareda et al., 2008). On the hand, bentonite is unsuitable substrate because it became pasty and sticky after water absorption and therefore does not produce proper ventilation conditions for aerobic bacterium Pseudomonas fluorescens (Khavazi and Rejali, 2000; Shariati et al., 2013). Due to lack of organic matter, low nutrient contents and water holding capacity of rock phosphate, it was not a good carrier for P. putida. 
Results suggested that the populations of $P$. putida were markedly higher in vermiculate than in other carriers when incubated for six months. Similarly, the populations of $P$. putida were approximately consistent over time in mixture of carrier $(\mathrm{R}+\mathrm{P}+\mathrm{B}+\mathrm{V})$. This result mainly attributed to its ion-exchange capacity that provides a good-buffered zone for $P$. putida during incubation period. Nakkeeran et al. (2006) stated that vermiculite has a high water holding capacity that is very an essential characteristic of a good carrier. Other previous studies have also shown that vermiculite is a good carrier for several biological control agents including Rhizobium spp. (Weiss-Graham et al., 1987), Azospirillum brasilense (Elazar and Yaakov, 1996), Pseudomonas fluorescens (Loccoz-Moënne et al.,1999) and Pichia anomala (Melin et al., 2006).
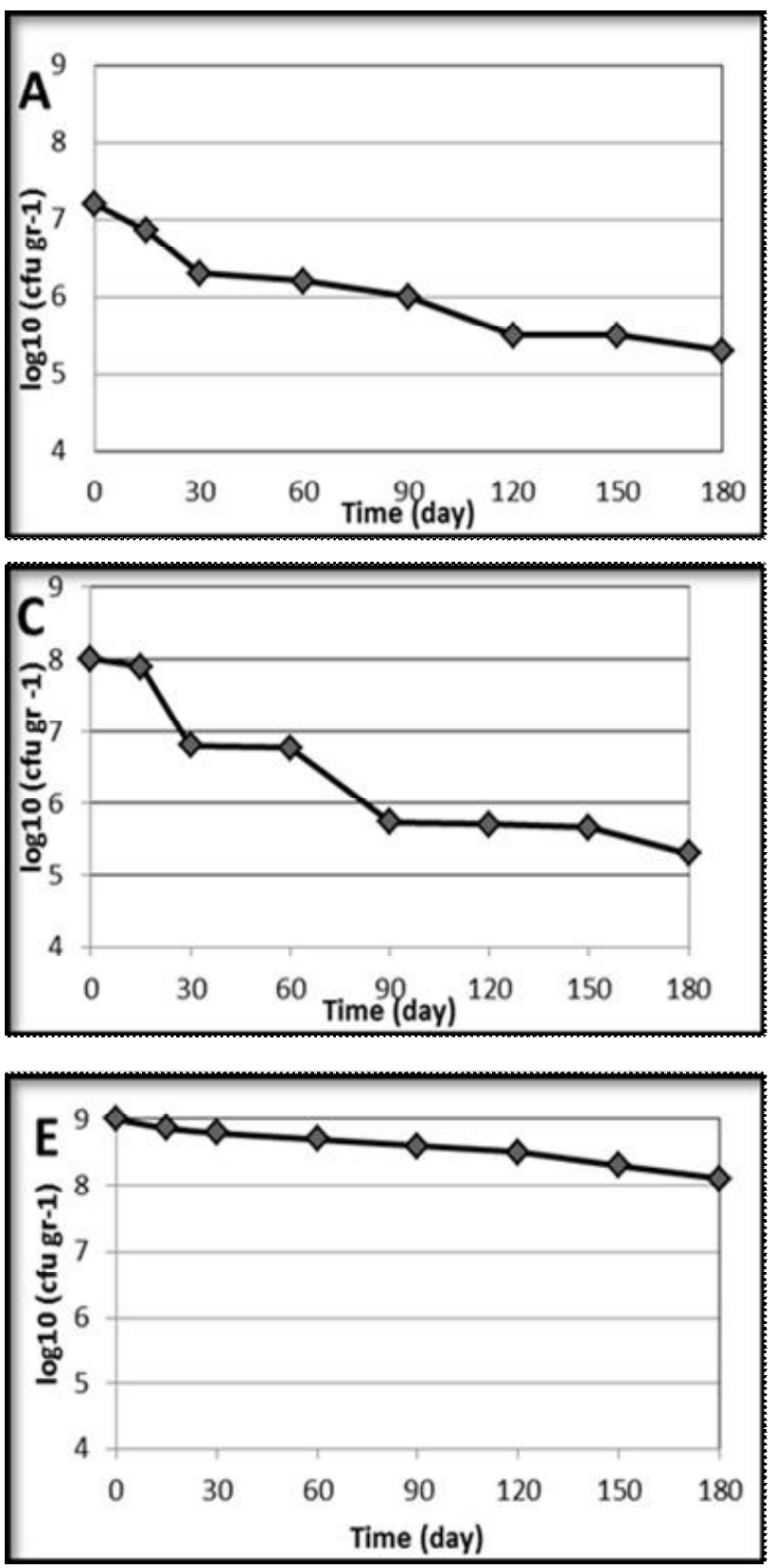

\section{CONCLUSION}

The present study revealed the biodiversity among antagonistic fluorescent pseudomonads and identified different species such as $P$. palleroniana, $P$. aeruginosa, $P$. putida, $P$. entomophila, $P$. moraviensis and $P$. plecoglossicida. The current study demonstrates the ability of fluorescent pseudomonad isolates to produce important secondary metabolite such as phenazine-1carboxylic acid, phenazine-1-carboxamide, pyoluteorin and pyrrolnitrin that known to have antifungal properties. The antagonistic bacteria exhibited the production of one or more fungal cell wall degrading enzymes. Based on the above mentioned result, among the evaluated carriers, vermiculite was found to be the best carrier, acting as both a substrate and food source for $P$. putida (SWA19).
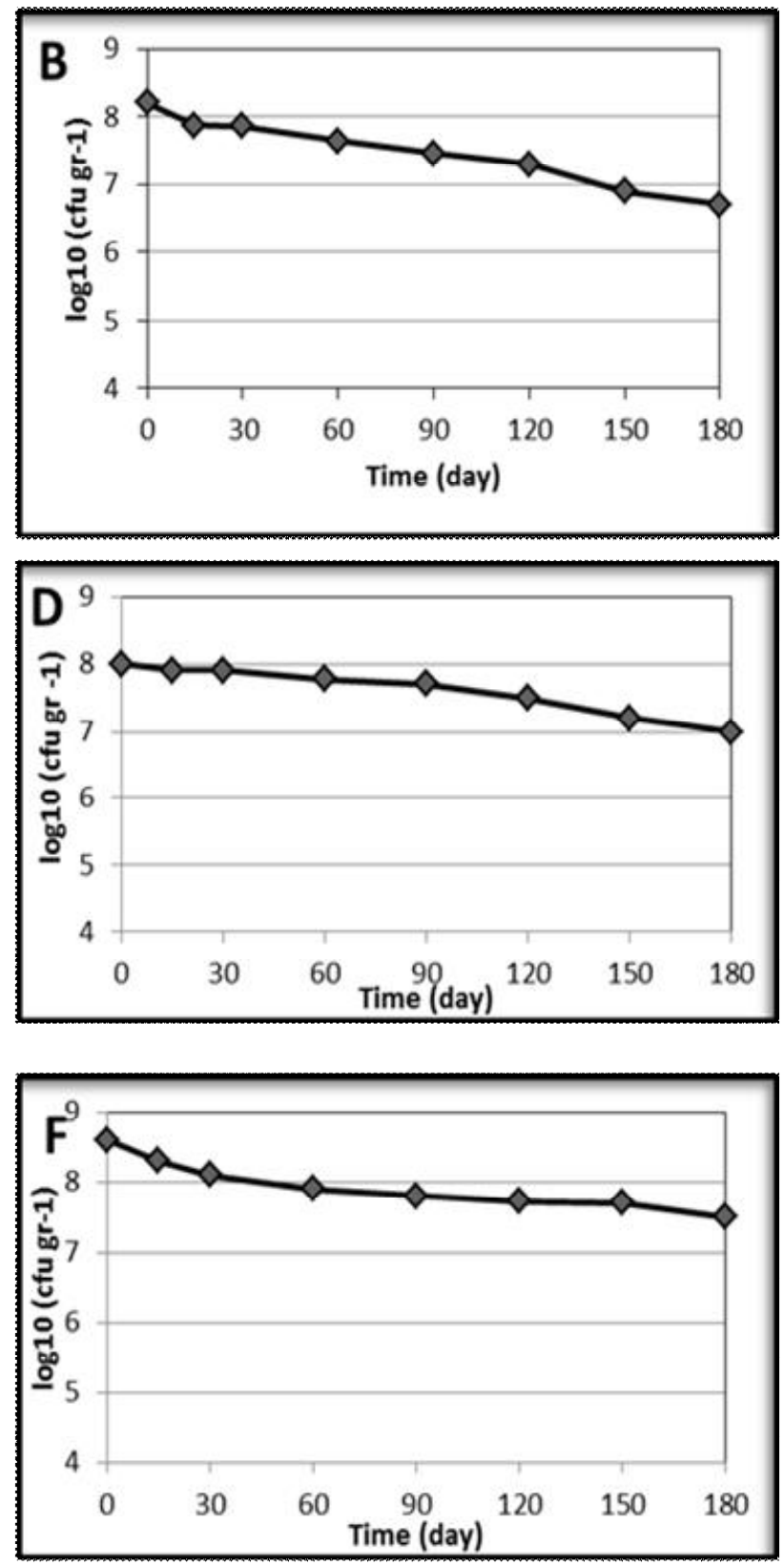

Fig. (6). Survival of Pseudomonas putida in different carrier materials at $28^{\circ} \mathrm{C}$ for six months, A(Rock phosphate), B (Perlite), C (Bentonite), D (Mixture from rock phosphate+ Perlite+ Bentonite), E (Vermiculite) and F (Mixture from rock phosphate + vermiculite + Perlite + Bentonite). 


\section{REFERENCES}

Albareda, M., D. N. Rodríguez-Navarro, M. Camacho and F. J. Temprano (2008). Alternatives to peat as a carrier for rhizobia inoculants: solid and liquid formulations. Soil Biol. Biochem., 40(11): 2771-2779.

Anjaiah, V., N. Koedam, B. Nowak-Thompson, J. E. Loper, M. Höfte, J. T. Tambong and P. Cornelis (1998). Involvement of Phenazines and Anthranilate in the Antagonism of Pseudomonas aeruginosa PNA1 and Tn 5 Derivatives Toward Fusarium spp. and Pythium spp., Mol. Plant Microbe Interact. 11(9): 847-854.

Atiyeh, R. M., S. Subler, C. A. Edwards, G. Bachman, J. D. Metzger and W. Shuster (2000). Effects of vermicomposts and composts on plant growth in horticultural container media and soil. Pedobiologia, 44(5): 579-590.

Bender, C. L., V. Rangaswamy and J. Loper (1999). Polyketide Production by Plant-Associated Pseudomonads. Ann. Rev. Phytopathol., 37(1): 175-196.

Brockwell, J., P. J. Bottomley and J. E. Thies (1995). Manipulation of rhizobia microflora for improving legume productivity and soil fertility: a critical assessment. In: Management of Biological Nitrogen Fixation for the Development of More Productive and Sustainable Agricultural Systems. pp. 143-180. Springer Netherlands.

Chin-A-Woeng, T. F., G. V. Bloemberg, A. J. Van Der Bij, K. M. Van Der Drift, J. Schripsema, B. Kroon and B. J. Lugtenberg (1998). Biocontrol by phenazine-1-carboxamide-producing Pseudomonas chlororaphis PCL1391 of tomato root rot caused by Fusarium oxysporum $f$. $s p$. radicis-lycopersici. Mol. Plant Microbe Interact., 11(11): 1069-1077.

Cigdem, K. and K. Merih (2005). Effect of formulation on the viability of biocontrol agent, Trichoderma harzıanum conidia. Afr. J. Biotechnol., 4(5): 483-486.

Daza, A., C. Santamarı, D. N. Rodrıguez-Navarro, M. Camacho, R. Orive and F. Temprano (2000). Perlite as a carrier for bacterial inoculants. Soil Biol. Biochem., 32(4): 567-572.

De Souza, J. T. and J. M. Raaijmakers (2003). Polymorphisms within the prnD and pltC genes from pyrrolnitrin and pyoluteorin-producing Pseudomonas and Burkholderia spp. FEMS Microbiol. Ecol., 43(1): 21-34.

Dwivedi, D. and B. N. Johri (2003). Antifungals from fluorescent pseudomonads: biosynthesis and regulation. Curr. Sci., 85(12): 1693-1703.

Einnarsson, S., S. Gudmundsson, H. Erlendsdottir, J. Moffat, W. Bayer and W. A. Craig (1993). The post-antibiotic effect of antimicrobial combinations in a neutropenic murine thigh infection model. J. Antimicrob. Chemother., 31(suppl D): 177-191.

Elazar, F. and O. Yaakov (1996). Inoculants of Azospirillum brasilense: biomass production, survival and growth promotion of Setaria italica and Zea mays. Soil Biol. Biochem., 28(1): 123126.

Goh, K. M. and R. J. Haynes (1977). Evaluation of potting media for commercial nursery production of container grown plants: III. Effects of media, fertiliser nitrogen, and a nitrification inhibitor on soil nitrification and nitrogen recovery of Callistephus chinensis (L.) Nees 'Pink Princess'. New Zeal. j. Agric. Res., 20(3): 383-393.

Gurusiddaiah, S., D. M. Weller, A. Sarkar and R. J. Cook (1986). Characterization of an antibiotic produced by a strain of Pseudomonas fluorescens inhibitory to Gaeumannomyces graminis var. tritici and Pythium spp. Antimicrob. Agents Chemother., 29(3): 488-495.

Hungria, M., J. C. Franchini, R. J. Campo and P. H. Graham (2005). The importance of nitrogen fixation to soybean cropping in South America. In: Nitrogen Fixation in Agriculture, Forestry, Ecology, and the Environment. pp. 25-42. Springer Netherlands.

Khavazi, K. and F. Rejali (2000). The use of some low cost materials as carrier for Bradyrhizobium japonicom, J. Soil Water, 14(1): 36-45.

Khavazi, K., F. Rejali, P. Seguin and M. Miransari (2007). Effects of carrier, sterilisation method, and incubation on survival of Bradyrhizobium japonicum in soybean (Glycine max L.) inoculants. Enzyme Microb. Technol., 41(6): 780-784.

Kumar, R. S., N. Ayyadurai, P. Pandiaraja, A. V. Reddy, Y. Venkateswarlu, O. Prakash and N. Sakthivel (2005). Characterization of antifungal metabolite produced by a new strain Pseudomonas aeruginosa PUPa3 that exhibits broad-spectrum antifungal activity and biofertilizing traits. J. Appl. Microbiol., 98(1): 145-154.

Ligon, J. M., D. S. Hill, P. E. Hammer, N. R. Torkewitz, D. Hofmann, H. J. Kempf and K. H. V. Pée (2000). Natural products with antifungal activity from Pseudomonas biocontrol bacteria. Pest Manag. Sci., 56(8): 688-695.

Loccoz-Moënne, Y., M. Naughton, P. Higgins, J. Powell, B. O'Connor and F. O'Gara (1999). Effect of inoculum preparation and formulation on survival and biocontrol efficacy of Pseudomonas fluorescens F113. J. Appl. Microbiol., 86(1): 108-116.

Mark, M., D. K. Fujimoto, L. S. Thomashow and R. J. Cook (1995). Variation in sensitivity of Gaeumannomyces graminis to antibiotics produced by fluorescent Pseudomonas spp. and effect on biological control of take-all of wheat. Appl. Environ. Microbiol., 61(7): 2554-2559.

Mavrodi, D. V., R. F. Bonsall, S. M. Delaney, M. J. Soule, G. Phillips and L. S. Thomashow (2001). Functional analysis of genes for biosynthesis of pyocyanin and phenazine-1-carboxamide from Pseudomonas aeruginosa PAO1. J. Bacteriol., 183(21): 6454-6465. 
Mavrodi, O. V., N. Walter, S. Elateek, C. G. Taylor and P. A. Okubara (2012). Suppression of Rhizoctonia and Pythium root rot of wheat by new strains of Pseudomonas. Biol. Control, 62(2): 93-102.

Melin, P., S. Håkansson, T. H. Eberhard and J. Schnürer (2006). Survival of the biocontrol yeast Pichia anomala after long-term storage in liquid formulations at different temperatures, assessed by flow cytometry. J. Appl. Microbiol., 100(2): 264-271.

Moeinzadeh, A., F. Sharif-Zadeh, M. Ahmadzadeh and F. Tajabadi (2010). Biopriming of Sunflower (Helianthus annuus L.) Seed with Pseudomonas fluorescens for Improvement of Seed Invigoration and Seedling Growth. Aust. J. Crop Sci., 4(7): 564-570.

Nakkeeran, S., W. D. Fernando and Z. A. Siddiqui (2006). Plant growth promoting rhizobacteria formulations and its scope in commercialization for the management of pests and diseases. In: PGPR: Biocontrol and Biofertilization. pp. 257296. Springer Netherlands.

Perneel, M., J. Heyrman, A. Adiobo, K. De Maeyer, J. M. Raaijmakers, P. De Vos and M. Höfte (2007). Characterization of CMR5c and CMR12a, novel fluorescent Pseudomonas strains from the cocoyam rhizosphere with biocontrol activity. J. Appl. Microbiol., 103(4): 1007-1020.

Pierson, L. S. and L. S. Thomashow (1992). Cloning and heterologous expression of the phenazine biosynthetic locus from Pseudomonas aureofaciens 30-84. Mol. Plant Microbe Interact., 5(4): 330-339.

Raaijmakers, J. M., I. de Bruijn and M. J. de Kock (2006). Cyclic lipopeptide production by plantassociated Pseudomonas spp.: diversity, activity, biosynthesis, and regulation. Mol. Plant Microbe Interact., 19(7): 699-710.

Raaijmakers, J. M., D. M. Weller and L. S. Thomashow (1997). Frequency of antibiotic-producing
Pseudomonas spp. in natural environments. Appl. Environ. Microbiol., 63(3): 881-887.

Rebah, F. B., R. D. Tyagi and D. Prévost (2002). Wastewater sludge as a substrate for growth and carrier for rhizobia: the effect of storage conditions on survival of Sinorhizobium meliloti. Bioresource technol., 83(2): 145-151.

Rivera-Cruz, M., A. T. Narcía, G. C. Ballona, J. Kohler, F. Caravaca and A. Roldan (2008). Poultry manure and banana waste are effective biofertilizer carriers for promoting plant growth and soil sustainability in banana crops. Soil Biol. Biochem., 40(12): 3092-3095.

Saber, Fakria M.A., A. A. Abdelhafez, E. A. Hassan and E. M. Ramadan (2015). Characterization of fluorescent pseudomonads isolates and their efficiency on the growth promotion of tomato plant. Annal. Agric. Sci., 60(1): 131-140.

Shariati, S., H. A. Alikhani, A. Pourbabaee and L. Mohammadi (2013). The potential of application of different organic and inorganic carriers in insoluble phosphate solubilizing bacteria (pseudomonas fluorescens) inoculants production process. Int. J. Agric.: Res. Rev., 3(1): 176-183.

Stephens, J. H. G. and H. M. Rask (2000). Inoculant production and formulation. Field Crop Res., 65(2): 249-258.

Strijdom, B. W. and C. C. Deschodt (1976). Carriers of rhizobia and the effects of prior treatment on the survival of rhizobia. In: Symbiotic Nitrogen Fixation in Plants. Nutman P. S. (ed.), pp: 151168. International Biological Programme 7. Cambridge University Press, London.

Weiss-Graham, L., M. L. Bennett and A. S. Paau (1987). Production of bacterial inoculants by direct fermentation on nutrient-supplemented vermiculite. Appl. Environ. Microbiol., 53(9): 2138-2141.

Weller, D. M. (2007). Pseudomonas biocontrol agents of soilborne pathogens: looking back over 30 years. Phytopathol., 97(2): 250-256. 